\title{
Vibrio variabilis sp. nov. and Vibrio maritimus sp. nov., isolated from Palythoa caribaeorum
}

Correspondence

Fabiano L. Thompson fabiano.thompson@biologia.ufr..br
Luciane A. Chimetto, ${ }^{1,2,3}$ Ilse Cleenwerck, ${ }^{3}$ Ana Paula B. Moreira, ${ }^{1}$ Marcelo Brocchi, ${ }^{2}$ Anne Willems, ${ }^{4}$ Paul De Vos ${ }^{3,4}$ and Fabiano L. Thompson ${ }^{1}$

\author{
${ }^{1}$ Institute of Biology, Federal University of Rio de Janeiro (UFRJ), Rio de Janeiro, Brazil \\ ${ }^{2}$ Department of Genetics, Evolution and Bioagents, Institute of Biology, State University of \\ Campinas (UNICAMP), Campinas, Brazil \\ ${ }^{3}$ BCCM/LMG Bacteria Collection, Ghent University, K. L. Ledeganckstraat 35, B-9000 Ghent, \\ Belgium \\ ${ }^{4}$ Laboratory of Microbiology, Faculty of Sciences, Ghent University, K. L. Ledeganckstraat 35, \\ B-9000 Ghent, Belgium
}

Zoanthids of the genus Palythoa are widespread around the world, most notably on rocky shores and coral reefs. Palythoa caribaeorum may cover up to $50 \%$ of the total area of rocky shores in some locations on the coast of Brazil

Abbreviations: DDH, DNA-DNA hybridization; MLSA, multilocus sequence analysis.

The GenBank/EMBL/DDBJ accession numbers for the sequences of Vibrio variabilis sp. nov. R- $40492^{\top}$ and Vibrio maritimus sp. nov. R40493 ${ }^{\top}$ are GU929924 and GU929925 (16S rRNA gene sequences), GU929926 and GU929927 (ftsZ gene sequences), GU929928 and GU929929 (gyrB gene sequences), GU929934 and GU929935 (recA gene sequences), GU929936 and GU929937 (rpoA gene sequences), GU929938 and GU929939 (topA gene sequences), GU929932 and GU929933 (pyrH gene sequences), and GU929930 and GU929931 (mreB gene sequences), respectively.

Three supplementary tables and eight supplementary figures are available with the online version of this paper.
(Oigman-Pszczol et al., 2004). This organism is well known for its ability to produce a very potent nonproteinaceous toxin (palytoxin) and copious amounts of mucus. These features may allow it to occupy areas of periodic desiccation and intense sunlight stress. Palythoa caribaeorum is sympatric with several coral species (Mussismilia species) on the Brazilian coast, sharing the same habitat with the main Brazilian reef builders. Vibrios are widespread in the aquatic environment and are often found associated with various organisms ranging from plankton to animals (Thompson et al., 2004). In the last few years, particularly due to the application of genomic techniques, the taxonomy of Vibrio has improved and many novel species have been described (Chimetto et al., 2011; Sheu et al., 2011; Wang et al., 2011). There are now over 84 formally described species in the genus (http://www.vibriobiology.net/). Some Vibrio species have been described that cause severe infections in humans 
and in many marine organisms (i.e. fish, crustaceans, molluscs and coral), but vibrios are also considered to be part of the normal microbiota of marine invertebrates and fish (Thompson et al., 2004; Gomez-Gil et al., 2007; Bourne et al., 2009). Vibrio neptunius, Vibrio brasiliensis and Vibrio sinaloensis have been found in association with healthy marine organisms (Thompson et al., 2003; Gomez-Gil et al., 2008), whereas Vibrio coralliilyticus has been described as one of the main coral pathogens around the world (BenHaim et al., 2003; Sussman et al., 2008).

In a survey on the diversity of heterotrophic bacteria associated with Palythoa caribaeorum in São Paulo (Brazil), two novel Vibrio strains, R-40492 ${ }^{\mathrm{T}}\left(=\mathrm{LMG} 25438^{\mathrm{T}}\right)$ and R$40493^{\mathrm{T}}\left(=\mathrm{LMG} 25439^{\mathrm{T}}\right)$, were obtained from mucus of apparently healthy Palythoa caribaeorum, located at two sites [Preta beach $\left(23^{\circ} 49^{\prime} 10^{\prime \prime} \mathrm{S} 45^{\circ} 24^{\prime} 37^{\prime \prime} \mathrm{W}\right)$ and Portinho beach $\left(23^{\circ} 50^{\prime} 25^{\prime \prime} \mathrm{S} 45^{\circ} 24^{\prime} 22^{\prime \prime} \mathrm{W}\right)$ ] (Chimetto et al., 2008, 2009). They were isolated on thiosulfatecitrate-bile salt-sucrose (TCBS; Oxoid) agar after $48 \mathrm{~h}$ incubation at $28{ }^{\circ} \mathrm{C}$. The aim of the present study was to perform a detailed taxonomic characterization of the two novel strains based on a polyphasic approach.

Sequences of $16 \mathrm{~S}$ rRNA, cell division protein $(f t s Z)$, DNA gyrase B subunit $(g y r B)$, recombination repair protein $(\operatorname{rec} A)$, RNA polymerase alpha subunit gene (rpoA), topoisomerase I (topA), uridylate kinase $(p y r H)$ and actinlike cytoskeleton protein $(m r e B)$ genes were obtained as described previously (Sawabe et al., 2007; Thompson et al., 2001a, 2007). Briefly, PCR products were purified with the enzyme Exosap according to the instructions of the manufacturer (GE Health Care). Subsequently, $5 \mu$ purified PCR product was mixed with $4 \mu$ l ET Terminator Mix (GE Health Care), $0.6 \mu$ sequencing primers $\left(20 \mu \mathrm{mol} \mathrm{l}^{-1}\right)$ and $0.4 \mu \mathrm{l}$ MilliQ water. The thermal program consisted of 30 cycles of $20 \mathrm{~s}$ at $95{ }^{\circ} \mathrm{C}, 15 \mathrm{~s}$ at $50{ }^{\circ} \mathrm{C}$ and $1 \mathrm{~min}$ at $60{ }^{\circ} \mathrm{C}$. Purification of the sequencing products was done by adding $1 \mu \mathrm{l}$ ammonium acetate $\left(7.5 \mathrm{~mol} \mathrm{l}^{-1}\right)$ and $27.5 \mu \mathrm{l}$ absolute ethanol to each product, incubating in the dark for $30 \mathrm{~min}$ and subsequent centrifugation at $20800 \mathrm{~g}$ for $75 \mathrm{~min}$ at $4{ }^{\circ} \mathrm{C}$. After this, the supernatant was removed and $100 \mu \mathrm{l}$ $70 \%$ ethanol was added. A final centrifugation step was performed at 3700 r.p.m. for $45 \mathrm{~min}$ at $4{ }^{\circ} \mathrm{C}$. Separation of the DNA fragments was performed using a MegaBace 1000 system (GE Health Care). Voltage and time of injection were $3 \mathrm{kV}$ and $80 \mathrm{~s}$, respectively. Running was performed at $9 \mathrm{kV}$ for $100 \mathrm{~min}$ at $44{ }^{\circ} \mathrm{C}$. Raw sequence data were transferred to ChromasPro version 1.34 (Technelysium, Tewantin, Australia) where consensus sequences were determined. Sequences were aligned using CluSTAL W. Pairwise similarities were calculated with the software BioNumerics 4.61 (Applied Maths, Belgium), using an open gap penalty of $100 \%$ and a unit gap penalty of $0 \%$, and with the software Jalview 2.4.0.b2 (Waterhouse et al., 2009). Similarity matrices and phylogenetic trees were constructed using the software MEGA version 4.0 (Tamura et al., 2007) and BioNumerics 4.61 (Applied Maths, Belgium). Trees were drawn using the neighbour-joining (Saitou \&
Nei, 1987) and maximum-parsimony methods (Eck \& Dayhoff, 1966). The robustness of each topology was checked by 1000 bootstrap replications (Felsenstein, 1985). The gene sequence data obtained in this study are also available through the website TAXVIBRIO (http:// www.taxvibrio.lncc.br/). The GenBank accession numbers for $f t s Z, g y r B, \quad r e c A, \quad r p o A, \operatorname{top} A, p y r H$ and $m r e B$ gene sequences used in this study are listed in Supplementary Table S1 (available in IJSEM Online). DNA-DNA hybridization (DDH) experiments were performed using Ezaki's microplate method as described previously in detail (Ezaki et al., 1989; Willems et al., 2001). The hybridization temperature was $40{ }^{\circ} \mathrm{C}$ in the presence of $50 \%$ formamide. Reciprocal reactions (e.g. $\mathrm{A} \times \mathrm{B}$ and $\mathrm{B} \times \mathrm{A}$ ) were performed for every DNA pair and their variation was within the limits of this method (Goris et al., 1998). The degree of DNADNA relatedness was also estimated using a fluorimetric method with SYBR Green I, by measuring the divergence between the thermal denaturation midpoint of homoduplex and heteroduplex DNA $\left(\Delta T_{\mathrm{m}}\right)$ as described by Moreira et al. (2011). The DDH experiments were performed four times. DNA $\mathrm{G}+\mathrm{C}$ contents were determined by HPLC as described previously (Mesbah et al., 1989). Analysis of fatty acid methyl esters was carried out as described by Huys et al. (1994). For fatty acid analysis, cells were grown on tryptone soy agar (TSA; Difco) supplemented with $1.5 \% \mathrm{NaCl}$ for $24 \mathrm{~h}$ at $28{ }^{\circ} \mathrm{C}$. Catalase activity was determined by adding young cells to a drop of $3 \% \mathrm{H}_{2} \mathrm{O}_{2}$ solution and observing $\mathrm{O}_{2}$ production. Oxidase activity was tested using $1 \% N, N, N^{\prime}, N^{\prime}$-tetramethyl $p$-phenylenediamine (Kovacs, 1956). Phenotypic characterization was performed using the API ZYM, API 20E (both bioMérieux) and Biolog GN2 metabolic fingerprinting kits as described previously (Thompson et al., 2001b, 2002). Type strains of closely related Vibrio species (i.e. V. neptunius LMG 20536 $6^{\mathrm{T}}, V$. coralliilyticus LMG $20984^{\mathrm{T}}$, Vibrio nigripulchritudo LMG $3896^{\mathrm{T}}, V$. sinaloensis LMG $25238^{\mathrm{T}}$ and $V$. brasiliensis LMG $\left.20546^{\mathrm{T}}\right)$ were included in these analyses. The temperature $\left(0-42{ }^{\circ} \mathrm{C}\right)$ and $\mathrm{pH}(4-13)$ ranges for growth were determined by incubating the isolates on TSA supplemented with $2 \%(\mathrm{w} / \mathrm{v}) \mathrm{NaCl}$. Growth at different $\mathrm{NaCl}$ concentrations $(0-14 \%, w / v)$ and $\mathrm{pH}$ were determined on TSA incubated for $72 \mathrm{~h}$ at $28{ }^{\circ} \mathrm{C}$. For $0 \% \mathrm{NaCl}$ concentration, TSA was prepared manually without the addition of salt. Acid production from sucrose was tested by incubating the isolates on TCBS agar. Traditional phenotypic tests (i.e. glucose fermentation, gas formation, hydrolysis of Tween 80, citrate utilization, activities of tryptophan deaminase, urease and lysine decarboxylase, and indole and $\mathrm{H}_{2} \mathrm{~S}$ production) were also performed as described previously (Macián et al., 2001).

Phylogenetic analysis based on 16S rRNA gene sequences of $\mathrm{R}-40492^{\mathrm{T}}$ (1521 bp) and R-40493 ${ }^{\mathrm{T}}(1504 \mathrm{bp})$ classified the novel strains in the genus Vibrio (Fig. 1). The two novel strains were most closely related to each other with $99 \%$ similarity, and to V. neptunius LMG $20536^{\mathrm{T}}$, V. coralliilyticus LMG $20984^{\mathrm{T}}, V$. nigripulchritudo LMG $3896^{\mathrm{T}}, V$. 


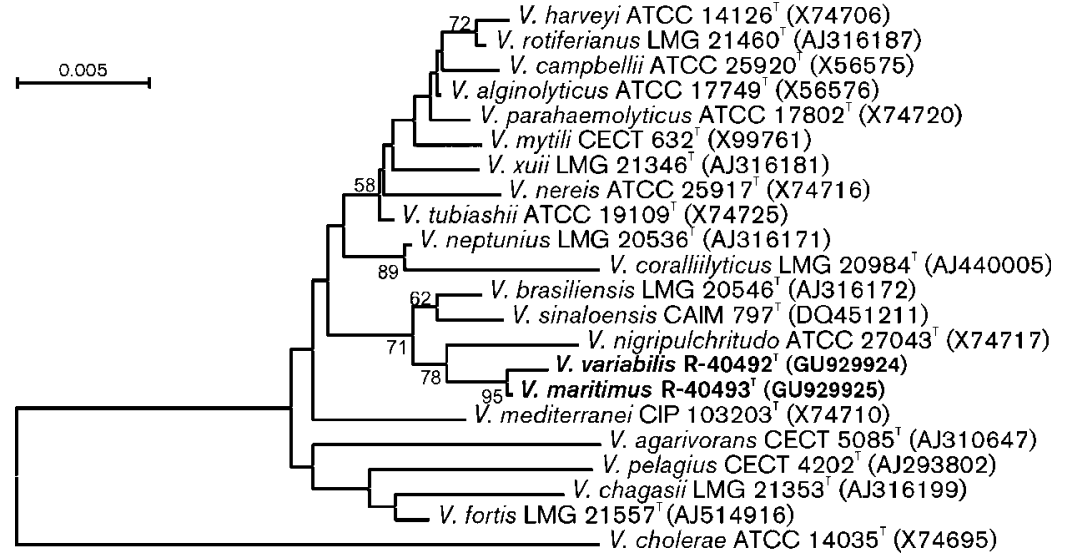

Fig. 1. Neighbour-joining phylogenetic tree showing the phylogenetic position of $V$. variabilis sp. nov. and $V$. maritimus $\mathrm{sp}$. nov. based on 16S rRNA gene sequences. Evolutionary distances were computed using the Jukes-Cantor method. All positions containing alignment gaps and missing data were eliminated only in pairwise sequence comparisons (pairwise deletion option). Phylogenetic analyses were conducted in MEGA4. Bootstrap values $(>50 \%)$ based on 1000 repetitions are shown. Vibrio cholerae ATCC $14035^{\top}$ was used as outgroup. Bar, $0.5 \%$ estimated sequence divergence. Fragments of $1521 \mathrm{bp}$ and $1504 \mathrm{bp}$ were obtained for $V$. variabilis and $V$. maritimus, respectively. sinaloensis LMG $25238^{\mathrm{T}}$ and $V$. brasiliensis $\mathrm{LMG} 20546^{\mathrm{T}}$ with similarities of $97.1-98.5 \%$ (Table 1).

Trees based on partial sequences of the housekeeping genes ftsZ (525 bp), gyrB (743 bp), recA (556 bp), rpoA (790 bp), topA (553 bp), pyrH (531 bp) and mreB (830 bp) confirmed the phylogenetic position of the two isolates in the genus Vibrio and revealed they constitute a separate branch (Supplementary Figs S1-S8, available in IJSEM Online). Similarities between R- $40492^{\mathrm{T}}$ and R- $40493^{\mathrm{T}}$ were $94.5 \%$ (for $\mathrm{ftsZ}$ ), $95.4 \%$ (for $\operatorname{gyr} B$ ), $95.7 \%$ (for $r e c A$ ), $98.5 \%$ (for rpoA), $97.8 \%$ (for topA), $96.7 \%$ (for pyrH) and $95.6 \%$ (for $m r e B$ ), which confirms their close relationship to each other. Although the similarities obtained for some housekeeping genes (i.e. pyrH) between R- $40492^{\mathrm{T}}$ and R$40493^{\mathrm{T}}$ are above the limiting value (>94-95\%) for species differentiation suggested by Thompson et al. (2005, 2009), data from multilocus sequence analysis (MLSA) clearly split these two novel strains in two phylogenetic branches (Fig. 2). Gene sequence similarities among R- $40492^{\mathrm{T}}$, R$40493^{\mathrm{T}}$ and the type strains of the phylogenetically most closely related species (i.e. V. neptunius, V. coralliilyticus, $V$. nigripulchritudo and $V$. brasiliensis), for which these housekeeping gene sequences were available in GenBank/ EMBL or the website TAXVIBRIO (http://www.taxvibrio. lncc.br/), were less than $92 \%$ (Supplementary Table S2 available in IJSEM Online). A neighbour-joining tree based on concatenated gene sequences of $16 \mathrm{~S}$ rRNA, fts $Z$, gyrB, recA, rpoA, topA, pyrH and mreB (6035 bp in length) confirmed the separate phylogenetic position of the novel strains R-40492 ${ }^{\mathrm{T}}$ and R-40493 ${ }^{\mathrm{T}}$ in the genus Vibrio, with high bootstrap support values in both neighbour-joining and maximum-parsimony methods (Fig. 2).

DDH experiments were performed with strains R- $40492^{\mathrm{T}}$, $\mathrm{R}-40493^{\mathrm{T}}$ and the type strains of the closest phylogenetic neighbours (Table 1). Results showed that the novel strains R-40492 ${ }^{\mathrm{T}}$ and R-40493 ${ }^{\mathrm{T}}$ had 55-57\% mutual DNA-DNA relatedness. This value is below the threshold for species delineation, considering the deviation of the methodology which is known to be around $7 \%$. DNA-DNA relatedness towards other species was $15 \%$ (Table 1). DNA-DNA relatedness estimates using a $\Delta T_{\mathrm{m}}$ method confirmed that strains R-40492 ${ }^{\mathrm{T}}$ and $\mathrm{R}-40493^{\mathrm{T}}$ should be classified as different species. The $\Delta T_{\mathrm{m}}$ value between $\mathrm{R}-40492^{\mathrm{T}}$ and $\mathrm{R}$ $40493^{\mathrm{T}}$ was $6.12{ }^{\circ} \mathrm{C}$ (Fig. 3), which is significantly above

Table 1. DNA-DNA hybridization data and $16 S$ rRNA gene sequence similarities of $V$. variabilis sp. nov., $V$. maritimus sp. nov. and related Vibrio species

Values are means. Standard deviations are given in parentheses.

\begin{tabular}{|c|c|c|c|c|c|c|c|c|c|}
\hline \multirow[t]{2}{*}{ Strain } & \multicolumn{2}{|c|}{$16 S$ rRNA similarity (\%) } & \multicolumn{7}{|c|}{ DNA-DNA hybridization values (\%) } \\
\hline & 1 & 2 & 1 & 2 & 3 & 4 & 5 & 6 & 7 \\
\hline 2. V. maritimus sp. nov. R- $40493^{\mathrm{T}}$ & 99.0 & 100 & $55(7)$ & 100 & $13(2)$ & $11(2)$ & $2(1)$ & $7(1)$ & $8(2)$ \\
\hline 3. V. neptunius LMG $20536^{\mathrm{T}}$ & 98.5 & 97.1 & $8(3)$ & $9(3)$ & 100 & $33(6)$ & $4(2)$ & $8(4)$ & $14(4)$ \\
\hline 4. V. coralliilyticus LMG $20984^{\mathrm{T}}$ & 98.2 & 97.3 & $9(2)$ & $11(3)$ & $48(7)$ & 100 & $3(2)$ & $11(5)$ & $12(4)$ \\
\hline 7. V. brasiliensis $\mathrm{LMG} 20546^{\mathrm{T}}$ & 98.1 & 98.4 & $15(1)$ & $13(2)$ & $24(6)$ & $22(7)$ & $6(2)$ & $14(4)$ & 100 \\
\hline
\end{tabular}




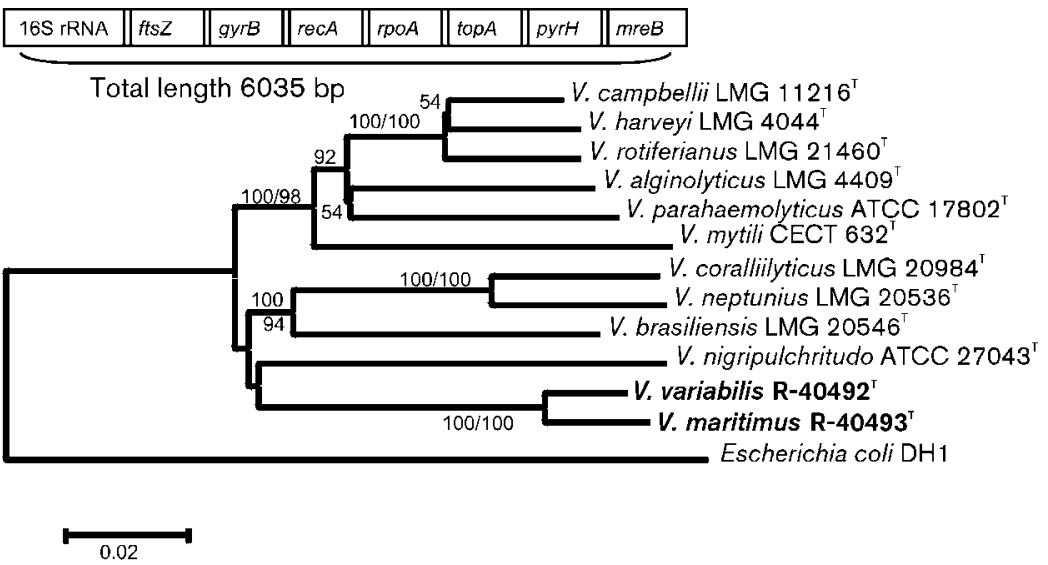

Fig. 2. Neighbour-joining phylogenetic tree showing the phylogenetic position of $V$. variabilis sp. nov. and $V$. maritimus sp. nov. based on concatenated 16S rRNA, ftsZ, gyrB, recA, rpoA, top $A$, pyrH and mreB gene sequences (6035 bp). Evolutionary distances were computed using the Jukes-Cantor method. Phylogenetic analyses were conducted in MEGA4. Bootstrap values $(>50 \%)$ based on 1000 repetitions are shown. Numbers at nodes denote bootstrap values derived from the neighbourjoining and maximum-parsimony methods, respectively; single values were obtained by neighbourjoining analysis. Escherichia coli $\mathrm{DH} 1$ was used as outgroup. Bar, $2 \%$ estimated sequence divergence.

the $5{ }^{\circ} \mathrm{C}$ cut-off level recommended for species delineation (Wayne et al., 1987; Rosselló-Mora \& Amann, 2001). The regression curve of the DDH versus $\Delta T_{\mathrm{m}}$ values determined by Moreira et al. (2011) indicates that the $\Delta T_{\mathrm{m}}$ expected for DDH between R-40492 ${ }^{\mathrm{T}}$ and R-40493 ${ }^{\mathrm{T}}$ should be $6.42{ }^{\circ} \mathrm{C}$, indicating a good correlation between the data. DDH data clearly provide evidence that the two novel strains should be allocated to two novel Vibrio species.

The two novel strains shared the main phenotypic and chemotaxonomic features of the genus Vibrio (Baumann \& Schubert, 1984). They were Gram-negative, motile, oxidase- and catalase-positive, and showed prolific growth on TCBS agar with production of acid from sucrose. The major fatty acids were summed feature 3 (comprising iso$\mathrm{C}_{15: 0} 2-\mathrm{OH}$ and/or $\left.\mathrm{C}_{16: 1} \omega 7 c\right), \mathrm{C}_{18: 1} \omega 7 c$ and $\mathrm{C}_{16: 0}$, which corresponded to $64 \%\left(\mathrm{R}-40492^{\mathrm{T}}\right)$ and $70 \%\left(\mathrm{R}-40493^{\mathrm{T}}\right)$ of the total fatty acids (Supplementary Table S3 available in IJSEM Online). Prolific growth occurred in TSA medium

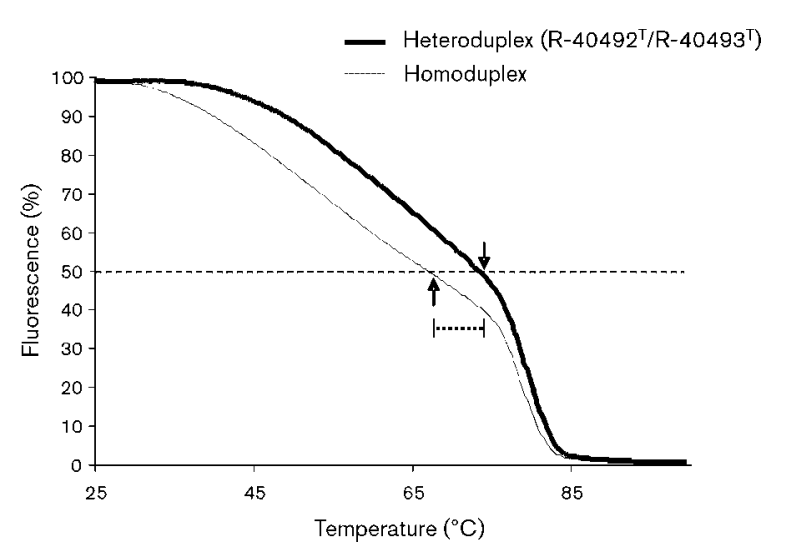

Fig. 3. Melting curves of homoduplex and heteroduplex (R$40492^{\top} / \mathrm{R}-40493^{\mathrm{T}}$ ) DNA. The $\Delta T_{\mathrm{m}}$ is: mean $6.12{ }^{\circ} \mathrm{C} \pm$ standard error of $0.26 ; n=8)$. The dashed horizontal line delimits a reduction of $50 \%$ in the fluorescence, reflecting a $50 \%$ denaturation of the double-stranded DNAs. containing $2.0 \%(\mathrm{w} / \mathrm{v}) \mathrm{NaCl}$ at $28{ }^{\circ} \mathrm{C}$; no growth was observed without $\mathrm{NaCl}$.

Phenotypic features such as acetoin production, activities of $N$-acetyl- $\beta$-glucosaminidase, $\beta$-galactosidase, trypsin, lipase (C14) and cystine arylamidase, fermentation of mannitol, inositol, L-rhamnose and amygdalin, and assimilation of D-glucuronic acid, $\alpha$-ketoglutaric acid, succinamic acid, glucuronamide, DL-carnitine, glucose 1-phosphate and glucose 6-phosphate can be used to differentiate the two novel species from each other and from phylogenetically related Vibrio species (Table 2). Divergent results were observed for indole production, assimilation of Tween 80 , and activities of tryptophan deaminase and lysine decarboxylase when traditional methods were compared with phenotypic characterization using the systems described in this study. The phenotypic profiles of each of the two novel strains are based on single isolates. However, five strains (R$77, \mathrm{R}-78^{\mathrm{T}}, \mathrm{R}-91^{\mathrm{T}}, \mathrm{R}-616$ and R-619), isolated as described by Chimetto et al. (2009), have been reported (Vibrio L2 sp. nov.) to be closely related based on $16 \mathrm{~S}$ rRNA and $p y r H$ gene sequences. Unfortunately, all strains apart from R- $78^{\mathrm{T}}$ $\left(=\mathrm{R}-40492^{\mathrm{T}}\right)$ and $\mathrm{R}-91^{\mathrm{T}}\left(=\mathrm{R}-40493^{\mathrm{T}}\right)$ lost viability. As more strains of these species are isolated and tested, the phenotypic profile may change slightly.

Based on data from polyphasic analysis including MLSA, DDH and phenotypic tests performed in this study, it is proposed that two novel species, Vibrio variabilis sp. nov. and Vibrio maritimus sp. nov., should be created to accommodate isolates $\mathrm{R}-40492^{\mathrm{T}}$ and R$40493^{\mathrm{T}}$, respectively.

\section{Description of Vibrio variabilis sp. nov.}

Vibrio variabilis (va.ri.a'bi.lis. L. masc. adj. variabilis changeable, variable, referring to the change of colour of the colonies).

Cells are $0.9 \mu \mathrm{m}$ wide and 1.5-2.5 $\mu \mathrm{m}$ long, Gram-negative, motile rods. Forms translucent, convex, smooth-rounded colonies with entire margins, $1 \mathrm{~mm}$ in size after 1 day 
Table 2. Differential features of $V$. variabilis sp. nov., V. maritimus sp. nov. and the most closely related Vibrio species

Strains: 1, V. variabilis sp. nov. R-40492 ${ }^{\mathrm{T}}$ (=LMG $25438^{\mathrm{T}}$ ); 2, V. maritimus sp. nov. R-40493 ${ }^{\mathrm{T}}\left(=\mathrm{LMG} 25439^{\mathrm{T}}\right.$ ); 3, V. neptunius LMG 20536 L $^{\mathrm{T}}$, V. coralliilyticus $\mathrm{LMG} 20984^{\mathrm{T}}$; 5, V. nigripulchritudo LMG $3896^{\mathrm{T}} ; 6$, V. sinaloensis LMG $25238^{\mathrm{T}} ; 7$, V. brasiliensis LMG 20546 ${ }^{\mathrm{T}}$. +, Positive; -, negative; $\mathrm{W}$, weak; ND, not determined. All data were obtained in this study except where indicated otherwise.

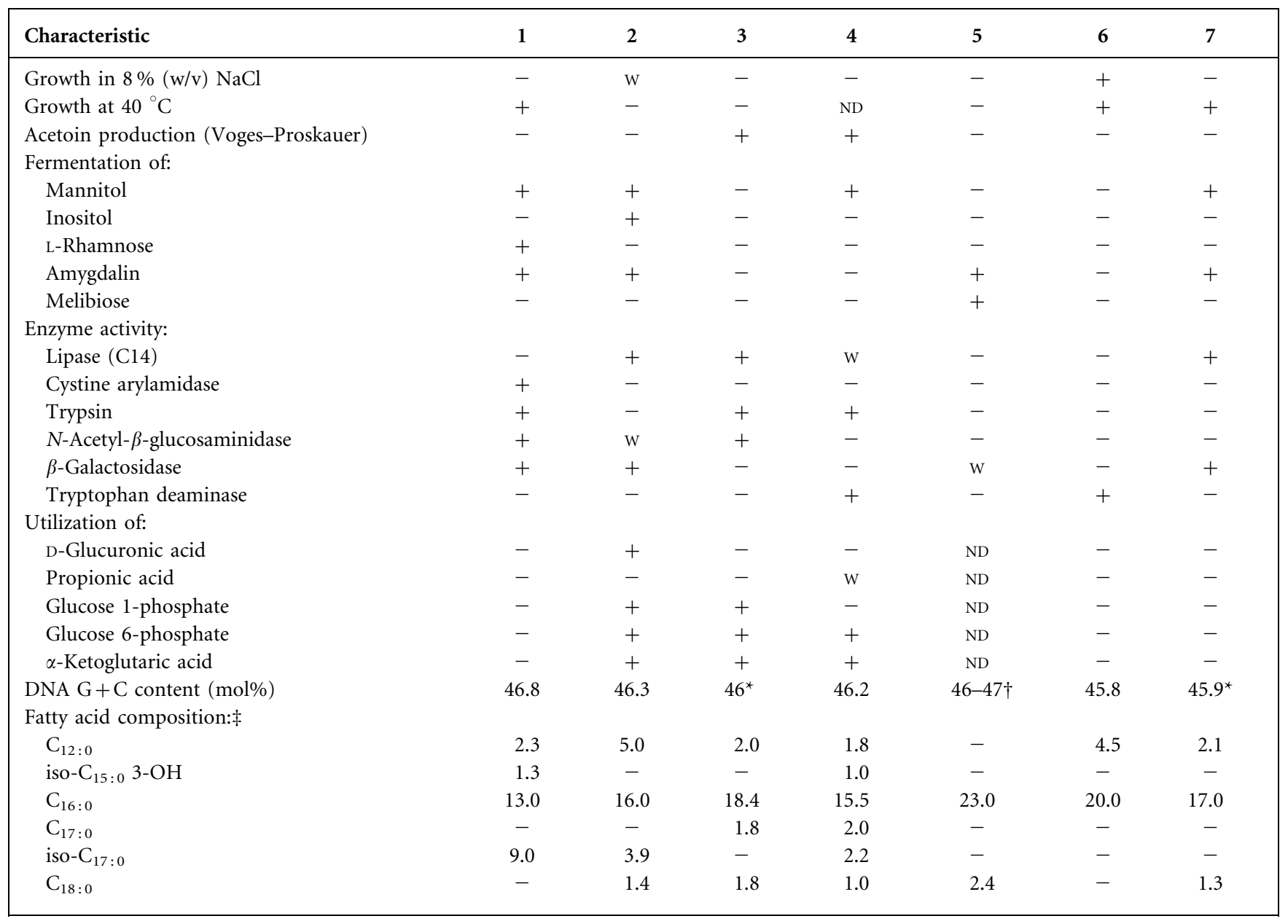

*Thompson et al. (2003).

$\dagger$ Baumann \& Schubert (1984).

\$Fatty acid profiles of known Vibrio species (type strain) were obtained in this study under the same conditions. Data are expressed as percentages of total fatty acids. Fatty acids representing $<1 \%$ are not shown.

incubation at $28^{\circ} \mathrm{C}$ on TSA. Colonies are beige in colour, but may turn black after some time under limited light conditions. Growth occurs between 15 and $40{ }^{\circ} \mathrm{C}$, at $\mathrm{NaCl}$ concentrations of $0.5-7.0 \%(\mathrm{w} / \mathrm{v})$ and at $\mathrm{pH} 6-12$. No growth is observed in 0 or $\geqslant 8 \% \mathrm{NaCl}$, at temperatures $\leqslant 7$ or $\geqslant 42{ }^{\circ} \mathrm{C}$, or at $\mathrm{pH} \geqslant 5$. Optimum growth occurs at 28 $35{ }^{\circ} \mathrm{C}$, in $1.5-5.0 \% \mathrm{NaCl}$ and at $\mathrm{pH} 7-10$. Yellow colonies are able to grow on the selective medium TCBS (positive for acid production from sucrose). Positive for alkaline phosphatase, esterase (C4), esterase lipase (C8), leucine arylamidase, acid phosphatase, naphthol-AS-BI-phosphohydrolase, $\alpha$-galactosidase, $\beta$-galactosidase, $\alpha$-glucosidase, arginine dihydrolase, gelatinase, valine arylamidase, cystine arylamidase, trypsin, $N$-acetyl- $\beta$-glucosaminidase, indole production, fermentation of glucose, mannitol, sucrose, amygdalin and rhamnose, nitrate reduction to nitrite, and assimilation of dextrin, glycogen, Tween 40, Tween $80, \mathrm{~N}$ acetyl-D-glucosamine, cellobiose, D-fructose, D-galactose, gentiobiose, $\alpha$-D-glucose, maltose, D-mannitol, D-mannose, melibiose, methyl $\beta$-D-glucoside, psicose, raffinose, Dsorbitol, sucrose, trehalose, turanose, methyl pyruvate, acetic acid, DL-lactic acid, succinic acid, alaninamide, Lalanine, L-alanyl glycine, L-asparagine, L-glutamic acid, glycyl-L-aspartic acid, glycyl-L-glutamic acid, L-serine, Lthreonine, inosine, uridine, thymidine, glycerol, DL- $\alpha-$ glycerol phosphate and $\alpha$-hydroxybutyric acid. Negative for $\alpha$-chymotrypsin, $\beta$-glucuronidase, $\beta$-glucosidase, $\alpha$ mannosidase, $\alpha$-fucosidase, lysine decarboxylase, ornithine decarboxylase, tryptophan deaminase, urease, lipase (C14), production of $\mathrm{H}_{2} \mathrm{~S}$ and acetoin (Voges-Proskauer), 
reduction of nitrate to $\mathrm{N}_{2}$ gas, fermentation of sorbitol, melibiose, arabinose and inositol, and assimilation of $\alpha$-cyclodextrin, citrate, $N$-acetyl-D-galactosamine, adonitol, L-arabinose, D-arabitol, $i$-erythritol, L-fucose, myo-inositol, $\alpha$-lactose, lactulose, L-rhamnose, xylitol, monomethyl succinate, cis-aconitic acid, citric acid, formic acid, D-galactonic acid lactone, D-galacturonic acid, D-gluconic acid, Dglucosaminic acid, $\beta$-hydroxybutyric acid, $\gamma$-hydroxybutyric acid, $p$-hydroxyphenylacetic acid, itaconic acid, $\alpha$-ketobutyric acid, $\alpha$-ketovaleric acid, malonic acid, propionic acid, quinic acid, D-saccharic acid, sebacic acid, bromosuccinic acid, D-alanine, L-aspartic acid, L-histidine, hydroxy-Lproline, L-leucine, L-ornithine, L-phenylalanine, L-proline, L-pyroglutamic acid, D-serine, $\gamma$-aminobutyric acid, urocanic acid, phenylethylamine, putrescine, 2-aminoethanol, 2,3-butanediol, D-glucuronic acid, $\alpha$-ketoglutaric acid, succinamic acid, glucuronamide, DL-carnitine, glucose 1phosphate and glucose 6-phosphate. The main cellular fatty acids are summed feature 3 (iso- $\mathrm{C}_{15: 0} 2-\mathrm{OH}$ and/or $\left.\mathrm{C}_{16: 1} \omega 7 c\right), \mathrm{C}_{18: 1} \omega 7 c$ and $\mathrm{C}_{16: 0}$. The following fatty acids are present in small amounts: iso- $\mathrm{C}_{17: 0}, \mathrm{C}_{14: 0}$, iso- $\mathrm{C}_{15: 0}$, $\mathrm{C}_{12: 0}$, summed feature $2\left(\mathrm{C}_{14: 0} 3-\mathrm{OH}\right.$ and/or iso- $\mathrm{C}_{16: 1} \mathrm{I}$, an unidentified fatty acid with an equivalent chain-length of 10.928 and/or $\mathrm{C}_{12: 0}$ ALDE), iso- $\mathrm{C}_{13: 0}, \mathrm{C}_{12: 0} 3-\mathrm{OH}$ and iso- $\mathrm{C}_{15: 0} 3-\mathrm{OH}$.

The type strain is $\mathrm{R}-40492^{\mathrm{T}}\left(=\mathrm{LMG} 25438^{\mathrm{T}}=\mathrm{CAIM}\right.$ $1454^{\mathrm{T}}$ ), isolated from mucus of the zoanthid Palythoa caribaeorum in Preta Beach, São Sebastião channel, São Paulo, Brazil. The DNA G + C content of strain R $-40492^{\mathrm{T}}$ is $46.8 \mathrm{~mol} \%$.

\section{Description of Vibrio maritimus sp. nov.}

Vibrio maritimus (ma.ri'ti.mus. L. masc. adj. maritimus of the sea, marine).

Cells are $1 \mu \mathrm{m}$ wide and 1.5-4.0 $\mu \mathrm{m}$ long, Gram-negative, motile bacilli. Forms translucent, convex, smooth-rounded colonies with entire margins, $1 \mathrm{~mm}$ in size and beige in colour after 1 day incubation at $28{ }^{\circ} \mathrm{C}$ on TSA. Growth occurs between 15 and $37^{\circ} \mathrm{C}$, at $\mathrm{NaCl}$ concentrations of $0.5-8.0 \%(\mathrm{w} / \mathrm{v})$ and at $\mathrm{pH} 5-12$. Weak growth is observed in the presence of $8 \% \mathrm{NaCl}$ and at $\mathrm{pH}$. No growth is observed in 0 or $\geqslant 9 \% \mathrm{NaCl}$, at temperatures $\leqslant 7$ or $\geqslant 40{ }^{\circ} \mathrm{C}$, or at $\mathrm{pH} \geqslant 4$. Yellow colonies are able to grow on the selective medium TCBS (positive for acid production from sucrose). Optimum growth occurs at $28-37{ }^{\circ} \mathrm{C}$, in $1.5-6.0 \% \mathrm{NaCl}$ and at $\mathrm{pH} 7-10$. Positive for alkaline phosphatase, esterase (C4), esterase lipase (C8), leucine arylamidase, acid phosphatase, naphthol-AS-BIphosphohydrolase, $\alpha$-galactosidase, $\beta$-galactosidase, $\alpha$-glucosidase, arginine dihydrolase, gelatinase, lipase (C14), indole production, fermentation of glucose, mannitol, sucrose, amygdalin and inositol, nitrate reduction to nitrite, and assimilation of dextrin, glycogen, Tween 40, Tween $80, \mathrm{~N}$-acetyl-D-glucosamine, cellobiose, D-fructose, D-galactose, gentiobiose, $\alpha$-D-glucose, maltose, D-mannitol, D-mannose, melibiose, methyl $\beta$-D-glucoside, psicose, raffinose, D-sorbitol, sucrose, trehalose, turanose, methyl pyruvate, acetic acid, DL-lactic acid, succinic acid, alaninamide, L-alanine, L-alanyl-glycine, L-asparagine, L-glutamic acid, glycyl-L-aspartic acid, glycyl-L-glutamic acid, L-serine, L-threonine, inosine, uridine, thymidine, glycerol, DL- $\alpha$ glycerol phosphate, D-glucuronic acid, $\alpha$-ketoglutaric acid, succinamic acid, glucuronamide, DL-carnitine, glucose 1-phosphate and glucose 6-phosphate. Negative for $\alpha$ chymotrypsin, $\beta$-glucuronidase, $\beta$-glucosidase, $\alpha$-mannosidase, $\alpha$-fucosidase, lysine decarboxylase, ornithine decarboxylase, tryptophan deaminase, urease, cystine arylamidase, trypsin, production of $\mathrm{H}_{2} \mathrm{~S}$ and acetoin (Voges-Proskauer), reduction of nitrate to $\mathrm{N}_{2}$ gas, fermentation of sorbitol, melibiose, arabinose and rhamnose, and assimilation of $\alpha$-cyclodextrin, citrate, $N$ acetyl-D-galactosamine, adonitol, L-arabinose, D-arabitol, $i$-erythritol, L-fucose, myo-inositol, $\alpha$-lactose, lactulose, Lrhamnose, xylitol, monomethyl succinate, cis-aconitic acid, citric acid, formic acid, D-galactonic acid lactone, D-galacturonic acid, D-gluconic acid, D-glucosaminic acid, $\beta$-hydroxybutyric acid, $\gamma$-hydroxybutyric acid, $p$-hydroxyphenylacetic acid, itaconic acid, $\alpha$-ketobutyric acid, $\alpha$-ketovaleric acid, malonic acid, propionic acid, quinic acid, D-saccharic acid, sebacic acid, bromosuccinic acid, D-alanine, L-aspartic acid, L-histidine, hydroxy-L-proline, Lleucine, L-ornithine, L-phenylalanine, L-proline, L-pyroglutamic acid, D-serine, $\gamma$-aminobutyric acid, urocanic acid, phenylethylamine, putrescine, 2-aminoethanol and 2,3butanediol. Weak reactions are observed for $N$-acetyl- $\beta$ glucosaminidase, valine arylamidase and $\alpha$-hydroxybutyric acid assimilation. The main cellular fatty acids are summed feature 3 (comprising iso- $\mathrm{C}_{15: 0} 2-\mathrm{OH}$ and/or $\mathrm{C}_{16: 1} \omega 7 c$ ), $\mathrm{C}_{18: 1} \omega 7 \mathrm{c}$ and $\mathrm{C}_{16: 0}$. The following fatty acids are present in small amounts: $\mathrm{C}_{14: 0}, \mathrm{C}_{12: 0}$, iso- $\mathrm{C}_{17: 0}$, summed feature 2 $\left(\mathrm{C}_{14: 0} 3-\mathrm{OH}\right.$ and/or iso- $\mathrm{C}_{16: 1} \mathrm{I}$, an unidentified fatty acid with an equivalent chain-length of 10.928 and/or $\mathrm{C}_{12: 0}$ ALDE), $\mathrm{C}_{12: 0} 3-\mathrm{OH}$, iso- $\mathrm{C}_{15: 0}, \mathrm{C}_{18: 0}$ and iso- $\mathrm{C}_{13: 0}$.

The type strain is $\mathrm{R}-40493^{\mathrm{T}} \quad\left(=\mathrm{LMG} 25439^{\mathrm{T}}=\mathrm{CAIM}\right.$ $\left.1455^{\mathrm{T}}\right)$, isolated from mucus of the zoanthid Palythoa caribaeorum in Portinho Beach, São Sebastião Channel, São Paulo, Brazil. The DNA G + C content of strain R $-40493^{\mathrm{T}}$ is $46.3 \mathrm{~mol} \%$.

\section{Acknowledgements}

The authors acknowledge grants from FAPERJ, US Embassy, CAPES, FAPESP, CNPq and IFS. L.A.C. acknowledges a $\mathrm{PhD}$ scholarship provided by CNPq. The BCCM/LMG Bacteria Collection is supported by the Federal Public Planning Service-Science Policy, Belgium. We thank Katrien Engelbeen (LMG/BCCM), Stefanie Van Trappen (LMG/ BCCM), Alvaro Migotto (CEBIMAR-USP), Bruno Gomez-Gil, and Cristiane $\mathrm{C}$. Thompson for technical assistance and valuable comments.

\section{References}

Baumann, P. \& Schubert, R. H. W. (1984). Genus I. Vibrio. In Bergey's Manual of Systematic Bacteriology, vol. 1, pp. 518-538. Edited by N. R. Krieg \& J. G. Holt. Baltimore: Williams \& Wilkins. 
Ben-Haim, Y., Thompson, F. L., Thompson, C. C., Cnockaert, M. C., Hoste, B., Swings, J. \& Rosenberg, E. (2003). Vibrio coralliilyticus sp. nov., a temperature-dependent pathogen of the coral Pocillopora damicornis. Int J Syst Evol Microbiol 53, 309-315.

Bourne, D. G., Garren, M., Work, T. M., Rosenberg, E., Smith, G. W. \& Harvell, C. D. (2009). Microbial disease and the coral holobiont. Trends Microbiol 17, 554-562.

Chimetto, L. A., Brocchi, M., Thompson, C. C., Martins, R. C. R., Ramos, H. R. \& Thompson, F. L. (2008). Vibrios dominate as culturable nitrogen-fixing bacteria of the Brazilian coral Mussismilia hispida. Syst Appl Microbiol 31, 312-319.

Chimetto, L. A., Brocchi, M., Gondo, M., Thompson, C. C., GomezGil, B. \& Thompson, F. L. (2009). Genomic diversity of vibrios associated with the Brazilian coral Mussismilia hispida and its sympatric zoanthids (Palythoa caribaeorum, Palythoa variabilis and Zoanthus solanderi). J Appl Microbiol 106, 1818-1826.

Chimetto, L. A., Cleenwerck, I., Alves, N., Jr, Silva, B. S., Brocchi, M., Willems, A., De Vos, P. \& Thompson, F. L. (2011). Vibrio communis sp. nov., isolated from the marine animals Mussismilia hispida, Phyllogorgia dilatata, Palythoa caribaeorum, Palythoa variabilis and Litopenaeus vannamei. Int J Syst Evol Microbiol 61, 362-368.

Eck, R. V. \& Dayhoff, M. O. (1966). Atlas of Protein Sequence and Structure. Silver Springs, MD: National Biomedical Research Foundation.

Ezaki, T., Hashimoto, Y. \& Yabuuchi, E. (1989). Fluorometric deoxyribonucleic acid-deoxyribonucleic acid hybridization in microdilution wells as an alternative to membrane filter hybridization in which radioisotopes are used to determine genetic relatedness among bacterial strains. Int J Syst Bacteriol 39, 224-229.

Felsenstein, J. (1985). Confidence limits on phylogenies: an approach using the bootstrap. Evolution 39, 783-791.

Gomez-Gil, B., Fajer-Avila, E. \& García-Vargas, F. (2007). Vibrios of the spotted rose snapper Lutjanus guttatus Steindachner, 1869 from northwestern Mexico. J Appl Microbiol 102, 1518-1526.

Gomez-Gil, B., Fajer-Avila, E., Pascual, J., Macián, M. C., Pujalte, M. J., Garay, E. \& Roque, A. (2008). Vibrio sinaloensis sp. nov., isolated from the spotted rose snapper, Lutjanus guttatus Steindachner, 1869. Int J Syst Evol Microbiol 58, 1621-1624.

Goris, J., Suzuki, K., De Vos, P., Nakase, T. \& Kersters, K. (1998). Evaluation of a microplate DNA-DNA hybridization method compared with the initial renaturation method. Can J Microbiol 44, 1148-1153.

Huys, G., Vancanneyt, M., Coopman, R., Janssen, P., Falsen, E., Altwegg, M. \& Kersters, K. (1994). Cellular fatty-acid composition as a chemotaxonomic marker for the differentiation of phenospecies and hybridization groups in the genus Aeromonas. Int J Syst Bacteriol 44, 651-658.

Kovacs, N. (1956). Identification of Pseudomonas pyocyanea by the oxidase reaction. Nature 178, 703.

Macián, M. C., Ludwig, W., Aznar, R., Grimont, P. A. D., Schleifer, K. H., Garay, E. \& Pujalte, M. J. (2001). Vibrio lentus sp. nov., isolated from Mediterranean oysters. Int J Syst Evol Microbiol 51, 1449-1456.

Mesbah, M., Premachandran, U. \& Whitman, W. B. (1989). Precise measurement of the $\mathrm{G}+\mathrm{C}$ content of deoxyribonucleic acid by high performance liquid chromatography. Int J Syst Bacteriol 39, 159-167.

Moreira, A. P. B., Pereira, N., Jr \& Thompson, F. L. (2011). Usefulness of a real-time PCR platform for $\mathrm{G}+\mathrm{C}$ content and DNA-DNA hybridization estimations in vibrios. Int J Syst Evol Microbiol 61, 2379-2383.

Oigman-Pszczol, S. S., Figueiredo, M. A. O. \& Creed, J. C. (2004). Distribution of benthic communities on the tropical rocky subtidal of
Armação dos Búzios, southeastern Brazil. Mar Ecol (Berl) 25, 173190.

Rosselló-Mora, R. \& Amann, R. (2001). The species concept for prokaryotes. FEMS Microbiol Rev 25, 39-67.

Saitou, N. \& Nei, M. (1987). The neighbor-joining method: a new method for reconstructing phylogenetic trees. Mol Biol Evol 4, 406-425.

Sawabe, T., Kita-Tsukamoto, K. \& Thompson, F. L. (2007). Inferring the evolutionary history of vibrios by means of multilocus sequence analysis. J Bacteriol 189, 7932-7936.

Sheu, S. Y., Jiang, S. R., Chen, C. A., Wang, J. T. \& Chen, W. M. (2011). Vibrio stylophorae sp. nov., isolated from the reef-building coral Stylophora pistillata. Int J Syst Evol Microbiol 61, 2180-2185.

Sussman, M., Willis, B. L., Victor, S. \& Bourne, D. G. (2008). Coral pathogens identified for White Syndrome (WS) epizootics in the Indo-Pacific. PLoS ONE 3, e2393.

Tamura, K., Dudley, J., Nei, M. \& Kumar, S. (2007). MEGA4: Molecular Evolutionary Genetics Analysis (MEGA) software version 4.0. Mol Biol Evol 24, 1596-1599.

Thompson, F. L., Hoste, B., Vandemeulebroecke, K. \& Swings, J. (2001a). Genomic diversity amongst Vibrio isolates from different sources determined by fluorescent amplified fragment length polymorphism. Syst Appl Microbiol 24, 520-538.

Thompson, F. L., Hoste, B., Thompson, C. C., Huys, G. \& Swings, J. (2001b). The coral bleaching Vibrio shiloi Kushmaro et al. 2001 is a later synonym of Vibrio mediterranei Pujalte and Garay 1986. Syst Appl Microbiol 24, 516-519.

Thompson, F. L., Hoste, B., Vandemeulebroecke, K., Engelbeen, K., Denys, R. \& Swings, J. (2002). Vibrio trachuri Iwamoto et al. 1995 is a junior synonym of Vibrio harveyi (Johnson and Shunk 1936) Baumann et al. 1981. Int J Syst Evol Microbiol 52, 973-976.

Thompson, F. L., Li, Y., Gomez-Gil, B., Thompson, C. C., Hoste, B., Vandemeulebroecke, K., Rupp, G. S., Pereira, A., De Bem, M. M. \& other authors (2003). Vibrio neptunius sp. nov., Vibrio brasiliensis sp. nov. and Vibrio xuii sp. nov., isolated from the marine aquaculture environment (bivalves, fish, rotifers and shrimps). Int J Syst Evol Microbiol 53, 245-252.

Thompson, F. L., lida, T. \& Swings, J. (2004). Biodiversity of vibrios. Microbiol Mol Biol Rev 68, 403-431.

Thompson, F. L., Gevers, D., Thompson, C. C., Dawyndt, P., Naser, S., Hoste, B., Munn, C. B. \& Swings, J. (2005). Phylogeny and molecular identification of vibrios on the basis of multilocus sequence analysis. Appl Environ Microbiol 71, 5107-5115.

Thompson, F. L., Gomez-Gil, B., Vasconcelos, A. T. R. \& Sawabe, T. (2007). Multilocus sequence analysis reveals that Vibrio harveyi and $V$. campbellii are distinct species. Appl Environ Microbiol 73, 4279-4285.

Thompson, C. C., Vicente, A. C. P., Souza, R. C., Vasconcelos, A. T. R., Vesth, T., Alves, N., Jr, Ussery, D. W., lida, T. \& Thompson, F. L. (2009). Genomic taxonomy of vibrios. BMC Evol Biol 9, 1-16.

Wang, H., Liu, J., Wang, Y. \& Zhang, X. H. (2011). Vibrio marisflavi sp. nov., isolated from seawater. Int J Syst Evol Microbiol 61, 568-573.

Waterhouse, A. M., Procter, J. B., Martin, D. M. A., Clamp, M. \& Barton, G. J. (2009). Jalview Version 2 - a multiple sequence alignment editor and analysis workbench. Bioinformatics 25, 1189-1191.

Wayne, L. G., Brenner, D. J., Colwell, R. R., Grimont, P. A. D., Kandler, O., Krichevsky, M. I., Moore, L. H., Moore, W. E. C., Murray, R. G. E. \& other authors (1987). International Committee on Systematic Bacteriology. Report of the ad hoc committee on reconciliation of approaches to bacterial systematics. Int J Syst Bacteriol 37, 463-464.

Willems, A., Doignon-Bourcier, F., Goris, J., Coopman, R., de Lajudie, P., De Vos, P. \& Gillis, M. (2001). DNA-DNA hybridization study of Bradyrhizobium strains. Int J Syst Evol Microbiol 51, 1315-1322. 